\title{
FEMORAL NECK ARTHROPLASTY AFTER FAILED RESURFACING: BRIEF REPORT
}

\author{
R. M. SHERMAN, S. B. GOODMAN, J. SCHATZKER
}

Surface replacement of the hip was introduced as an alternative to conventional replacement. Unfortunately, its theoretical advantages have been overshadowed by the high incidence of early failure (Head 1981; Jolley, Salvati and Brown 1982; Bell et al. 1985). If failure necessitates removal of the prosthesis, we advocate preservation of the femoral neck stump for articulation. We report five such cases.

Patients and Methods. Five patients, each of whom had a Wagner resurfacing arthroplasty, later required excisional arthroplasty for loosening: three were aseptic, and two septic. The acetabular and femoral components were removed but the femoral stump was left intact (Fig. 1), except in patient $B$ who had an associated femoral neck fracture. In no case was any further acetabular bone stock resected. The femoral stump was placed in the acetabulum without any soft tissue interposition and the wounds closed primarily over suction drains. The patients were placed in traction for six weeks then allowed up taking as much weight as they would tolerate using walking aids. A shoe raise was used to compensate for leg length discrepancy.

Results. These are summarised in Table I. Except for patient B who had a femoral neck fracture, they were very satisfactory.

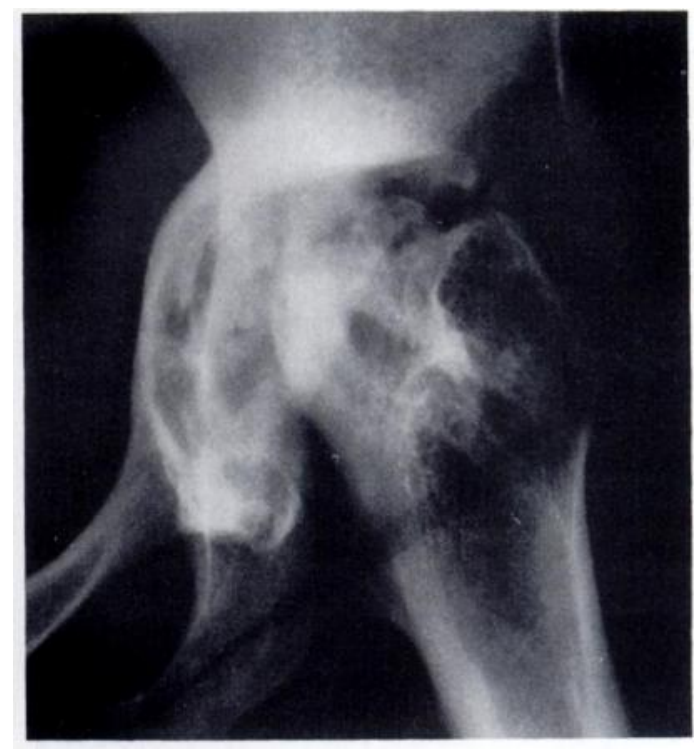

Fig. 1

Discussion. In Girdlestone's arthroplasty the entire femoral neck and the cartilage of the acetabulum are resected (Girdlestone 1943). In four of our five cases the femoral stump was not resected. Such relative lengthen-

Table I. Results in five patients

\begin{tabular}{|c|c|c|c|c|c|c|c|c|c|}
\hline \multirow[b]{2}{*}{ Patient } & \multirow[b]{2}{*}{$\begin{array}{l}\text { Follow-up } \\
\text { (months) }\end{array}$} & \multirow[b]{2}{*}{ Pain } & \multirow[b]{2}{*}{ Walking } & \multirow[b]{2}{*}{ Activities } & \multicolumn{5}{|c|}{ Hip movement in degrees } \\
\hline & & & & & Flexion & Abduction & Adduction & $\begin{array}{l}\text { Medial } \\
\text { rotation }\end{array}$ & $\begin{array}{l}\text { Lateral } \\
\text { rotation }\end{array}$ \\
\hline A & 71 & $\begin{array}{l}\text { None } \\
\text { No analgesics }\end{array}$ & $\begin{array}{l}\text { No cane } \\
\text { Walks } 60 \mathrm{~min}\end{array}$ & $\begin{array}{l}\text { Independent farmer } \\
\text { Stairs normal }\end{array}$ & 100 & 30 & 20 & 45 & 20 \\
\hline B & 30 & $\begin{array}{l}\text { Moderate } \\
\text { Simple } \\
\text { analgesics }\end{array}$ & $\begin{array}{l}\text { Cane indoors } \\
\text { Crutch outdoors } \\
\text { Walks } 10 \mathrm{~min}\end{array}$ & $\begin{array}{l}\text { Not working } \\
\text { No sports } \\
\text { Stairs difficult }\end{array}$ & 115 & 60 & 60 & 70 & 70 \\
\hline C & 51 & $\begin{array}{l}\text { Mild with } \\
\text { exercise } \\
\text { No analgesics }\end{array}$ & $\begin{array}{l}\text { No cane } \\
\text { Walks } 60 \mathrm{~min}\end{array}$ & $\begin{array}{l}\text { Dancing, tennis, } \\
\text { cycling } \\
\text { Stairs normal }\end{array}$ & 90 & 30 & 20 & 40 & 10 \\
\hline D & 91 & $\begin{array}{l}\text { None } \\
\text { No analgesics }\end{array}$ & $\begin{array}{l}\text { No cane } \\
\text { Walks } 60 \mathrm{~min}\end{array}$ & $\begin{array}{l}\text { Normal housework } \\
\text { Stairs, good leg first }\end{array}$ & 80 & 20 & 20 & 20 & 10 \\
\hline $\mathbf{E}$ & 24 & $\begin{array}{l}\text { Mild } \\
\text { NSAID }\end{array}$ & $\begin{array}{l}\text { Two canes } \\
\text { Walks } 10 \mathrm{~min}\end{array}$ & $\begin{array}{l}\text { Not working } \\
\text { Needs assistance } \\
\text { with } \mathrm{ADL}^{*}\end{array}$ & 90 & 30 & 25 & 40 & 10 \\
\hline
\end{tabular}

* activities of daily living 
ing of the femoral neck lever arm improves tension in the pelvi-trochanteric muscles, thus mitigating the abductor lurch; abductor power in no case was less than strength 4. Leg length discrepancy was $5 \mathrm{~cm}$ in three patients, $4 \mathrm{~cm}$ in one and $2 \mathrm{~cm}$ in the other. Moreover, trochanteric impingement on the acetabulum is reduced, thereby retaining functional abduction. We do not think that

R. M. Sherman, MD, FRCS, Clinical Assistant Professor University of Saskatchewan, 2-4101 Dewdney Avenue, Regina, Saskatchewan S4T IA5, Canada.

S. B. Goodman, BSc, MD, MSc, FRCSC, Assistant Professor Stanford University Medical Center, 300 Pasteur Drive, Division of Orthopaedic Surgery, Stanford, California 94305-5326, USA.

J. Schatzker, BSc, MD, FRCSC, Professor, University of Toronto, Chief of Orthopaedic Surgery

Sunnybrook Medical Center, Suite 3015, 2075 Bayview Avenue, Toronto, Ontario M4N 3M5, Canada.

Correspondence to Mr R. M. Sherman, Medical Centre, Pasqua Hospital, 2-4101 Dewdney Avenue, Regina, Saskatchewan S4T IA5, Canada.

(C) 1989 British Editorial Society of Bone and Joint Surgery $0301-620 X / 89 / 2 R 93 \$ 2.00$

J Bone Joint Surg [Br] 1989;71-B:330-1. trochanteric osteotomy and distal placement is indicated, as four of our five patients recovered good abductor strength. We believe that the procedure described provides long term salvage after failed resurfacing arthroplasty and should be considered in young patients in preference to revision to a total joint replacement, arthrodesis, or a conventional Girdlestone arthroplasty.

No benefits in any form have been received or will be received from a commercial party related directly or indirectly to the subject of this article.

\section{REFERENCES}

Bell RS, Schatzker J, Fornasier VI, Goodman SB. A study of implant failure in the Wagner resurfacing arthroplasty. J Bone Joint Surg [Am] 1985;67-A :1165-75.

Girdlestone GR. Acute pyogenic arthritis of the hip: an operation giving free access and drainage. Lancet 1943;i:419-21.

Head WC. Wagner surface replacement arthroplasty of the hip: analysis of fourteen failures in forty-one hips. J Bone Joint Surg [Am $] 1981 ; 63-A: 420-7$.

Jolley MN, Salvati EA, Brown GC. Early results and complications of surface replacement of the hip. J Bone Joint Surg [Am] $1982: 64-A: 366-7$

\section{LIPOFIBROMATOUS HAMARTOMA OF THE ULNAR NERVE AT THE ELBOW: BRIEF REPORT}

\section{R. GOULDESBROUGH, S. J. KINNY}

Lipofibromatous hamartoma is an uncommon lesion of peripheral nerves first described in 1953 by Mason. Several reports of this condition have appeared (Johnson and Bonfiglio 1969; Silverman and Enzinger 1985), but most cases have involved the median nerve in the distal forearm, wrist or palm and presented with carpal tunnel syndrome. Only two cases of involvement of the distal ulnar nerve have previously been reported (Silverman and Enzinger 1985).

Case Report. A 59-year-old man presented with an 18month history of progressive weakness of his left hand with some numbness around the elbow but no gross disturbance of sensation in the ulnar distribution. On examination, he had normal grip strength but loss of fine finger movements with paralysis and gross wasting of the ulnar intrinsic muscles. The ulnar-supplied forearm flexors were normal. There was minor sensory impairment in the ulnar distribution. Diffuse thickening of the ulnar nerve was palpable in the region of the ulnar groove behind the distal humerus.

At operation, the ulnar nerve was found to be diffusely expanded by fibrofatty tissue for $12 \mathrm{~cm}$ of its length (Fig. 1); $5 \mathrm{~cm}$ distal to the elbow it tapered to normal size but was pale and somewhat sclerotic. The branches to flexor carpi ulnaris were involved and one

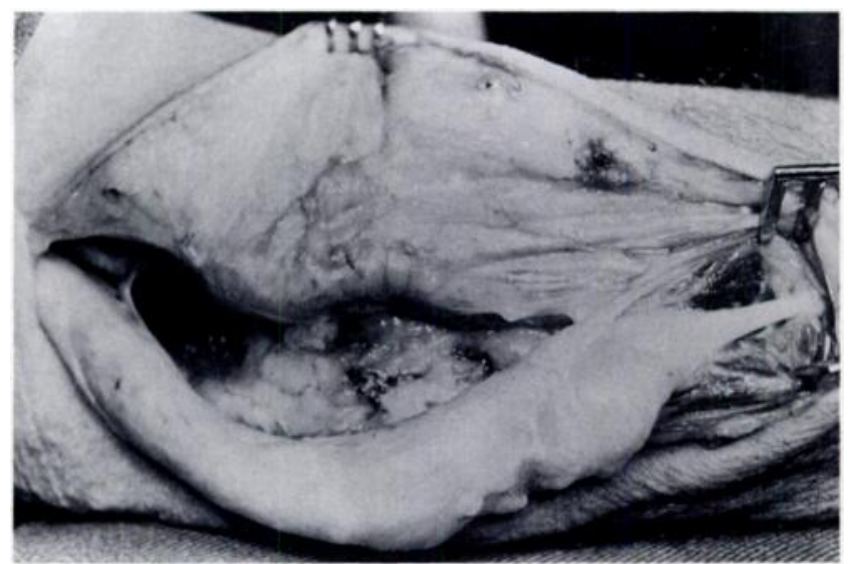

Fig. 1

was excised for histology. Diffuse involvement of the nerve prevented the removal of abnormal tissue; the nerve was simply decompressed, its bulk precluding transposition. At follow-up there was slight sensory improvement but no recovery of motor function.

Pathology. Two specimens were received for pathological examination. Each was irregular, fusiform, firm, white and translucent. They measured 1.8 and $2 \mathrm{~cm}$ in 